Relations industrielles

Industrial Relations

\title{
Heneman, Robert L., Merit Pay : Linking Pay Increases to Performance Ratings
}

\section{Marcel Bernard}

Volume 48, numéro 2, 1993

URI : https://id.erudit.org/iderudit/050866ar

DOI : https://doi.org/10.7202/050866ar

Aller au sommaire du numéro

Éditeur(s)

Département des relations industrielles de l'Université Laval

ISSN

0034-379X (imprimé)

1703-8138 (numérique)

Découvrir la revue

Citer ce compte rendu

Bernard, M. (1993). Compte rendu de [Heneman, Robert L., Merit Pay : Linking Pay Increases to Performance Ratings]. Relations industrielles / Industrial Relations, 48(2), 376-378. https://doi.org/10.7202/050866ar

Tous droits réservés @ C Département des relations industrielles de l'Université Laval, 1993
Ce document est protégé par la loi sur le droit d'auteur. L'utilisation des services d'Érudit (y compris la reproduction) est assujettie à sa politique d'utilisation que vous pouvez consulter en ligne.

https://apropos.erudit.org/fr/usagers/politique-dutilisation/ 
empiriques. Alternatives to Lean Production offre également une remarquable contribution au monde scientifique en regard de sa dimension comparative internationale.

Martin Dumas

Université Laval

Merit Pay: Linking Pay Increases to Performance Ratings, by Robert L. Heneman, Reading, MA., Addison-Wesley Publishing Co., 1992, 298 p., ISBN 0-201-52504-6

Les systèmes de rémunération liant les augmentations de salaires à la performance individuelle ou collective sont utilisés par les employeurs dans le but d'augmenter la motivation et la productivité des personnes à leur emploi. L'ouverture à des marchés plus vastes et plus compétitifs accentue l'importance de la productivité des entreprises.

Le livre de Robert L. Heneman traite principalement de la rémunération individuelle au mérite. Les objectifs de l'auteur sont doubles. Premièrement, présenter un cadre théorique de référence pour toute personne qui désire faire un rapide tour d'horizon des différents plans de rémunération au mérite qui sont appliqués le plus fréquemment dans les organisations. Deuxièmement, faire ressortir les apects pratiques qui doivent être considérés dans le processus de révision de la politique de rémunération d'une organisation pour accorder une plus grande importance à la performance individuelle. À mon sens, ce volume constitue un excellent guide pour un employeur qui voudrait s'engager dans cette direction.

Heneman définit la rémunération individuelle au mérite comme étant à la fois une formule de récompense et une mesure incitative. Il présente donc la rémunération au mérite comme une méthode qui sert à mesurer la performance antérieure d'une personne en vue d'influencer son comportement futur pour obtenir un niveau attendu de performance. Ce faisant, il procède à une énumération exhaustive des programmes de rémunération liée à la performance appliqués dans les entreprises à succès aux États-Unis et compare les programmes de rémunération basés sur le mérite individuel avec ceux basés sur le mérite collectif. Il examine aussi les effets de la rémunération au mérite individuel sur une longue période de temps, les distinguant ainsi des programmes collectifs dont les effets sont la plupart du temps limités dans le temps.

Le volume comprend sept chapitres et une bibliographie complète et à jour. Les deux premiers chapitres sont surtout consacrés à présenter une revue de la théorie derrière la rémunération liée à la performance et de la recherche actuelle dans ce domaine. Heneman y présente principalement deux théories qui sont à l'origine de ces programmes. La première est du domaine du comportement organisationnel; l'auteur fait le point sur les recherches qui ont examiné le lien entre la rémunération liée à la performance individuelle et l'augmentation de la motivation. La deuxième théorie plutôt du domaine économique considère l'augmentation de la performance comme un des facteurs qui influent sur l'augmentation de la productivité de l'organisation. 
La recherche actuelle ne permet pas de statuer hors de tout doute sur le lien de causalité entre les programmes de rémunération liée à la performance et l'augmentation de la productivité. Heneman conclut néanmoins à leur utilité comme politique de gestion de ressources humaines qui vise à mesurer et à reconnaître la performance individuelle et à en tenir compte dans la distribution de récompenses salariales, ce dernier aspect faisant référence à la notion de justice distributive souhaitable dans toute politique de rémumération.

Les chapitres suivants constituent un excellent guide pour toute personne qui s'intéresse à l'implantation d'un plan de rémunération au mérite dans une organisatisn. L'auteur insiste sur l'importance de bien diagnostiquer la situation de l'organisation en décrivant les caractéristiques environnementales, les conditions économiques et les caractéristiques de la main-d'œuvre qui sont favorables à l'implantation de ces programmes. Heneman insiste aussi sur la nécessité d'avoir une mesure adéquate de la performance puisqu'il est impossible de mettre en place un programme efficace si la mesure de la performance est inadéquate ou perçue comme telle par les personnes évaluées. Dans cette perspective, il décrit toute une gamme de méthodes qui visent à augmenter la fiabilité de l'évaluation, en passant par des indicateurs liés à la mission de l'organisation jusqu'à la formation et l'imputabilité des évaluateurs.

Finalement, les plans de rémunération au mérite amènent une récompense pécuniaire. L'auteur expose l'importance de lier les augmentations de salaires aux différents niveaux de performance et, puisque les effets financiers de ces augmentations se font sentir sur une longue période, il consacre aussi une attention particulière à la gestion des plans de rémunération au mérite pour maintenir l'équité et la justice dans la distribution des récompenses et de la nécessité qu'il en soit ainsi pour en favoriser l'efficacité.

La principale qualité de ce volume est qu'il permet au lecteur de faire rapidement le point sur l'état de la situation de la rémunération au mérite dans les entreprises américaines. En puisant dans la recherche de disciplines telles que les sciences sociales, la psychologie, l'économie, le management et les relations industrielles, Heneman présente la rémunération au mérite avec une approche multidisciplinaire.

Ce volume ne saurait cependant constituer à lui seul une référence adéquate sur cette question. Il s'adresse à différents types de lecteurs : les étudiants de niveaux universitaires pour qui il constitue un ouvrage complémentaire à d'autres lectures, les praticiens pour lesquels il peut servir de lecture préalale à l'implantation d'un programme de rémunération au mérite et les personnes qui s'intéressent à la recherche en matière de rémunération.

À mon sens les ojectifs de l'auteur ont été atteints pour les deux premières catégories de lecteurs. Il est particulièrement recommandé pour les professionnels qui touchent directement ou indirectement à la gestion de la rémunération. Ces personnes y trouveront plusieurs exemples d'implantation dans différents contextes organisationnels analysés et critiqués par l'auteur. Toutefois, ce volume sera d'une moins grande utilité pour la personne qui voudrait approfondir ses connaissances théoriques sur la rémunération au mérite. Après avoir porté ce jugement, je me dois cependant d'ajouter 
que la recherche sur l'utilité des systèmes de rémunération au mérite comme facteur d'augmentation de la motivation et de la productivité est pratiquement inexistante. Cette lacune est par ailleurs très bien identifiée par l'auteur qui conclut à la nécessité d'examiner avec plus de rigueur scientifique le préjugé favorable des gestionnaires à l'endroit des systèmes de rémunération basés sur la performance individuelle.

Marcel BERNARD

Université Laval

Worker Protection, Japanese Style: Occupational Safety and Health in the Auto Industry, by Richard E. WoKUTCH, New York, ILR Press, 1992, 263 p., ISBN 0-87546-186-7 (alk. paper), ISBN 0-87546-187-5 (alk. paper: pbk.)

The debate over the recent success of the Japanese automobile industry continues to be waged by trade unionists, policy makers and academics. The higher average number of days worked per year in Japan and the higher intensity of effort while at work, are believed by many to be critical in explaining the higher levels of Japanese labour productivity. This has raised concerns about the health and safety impact of the Japanese production system, and the phenomenon of death from over work, referred to as karoshi in Japan. Wokutch has made a significant contribution to this debate by examining the health and safety process in Japan and in Japanese transplants in the United States.

There is much to recommend in this book. It is sensitive to the historical context, the role of culture and values, and organizational issues such as worker empowerment in explaining health and safety performance. It also warns the reader of the difficulties non-Japanese scholar have understanding the nuances of Japanese actions.

The section on the history of health and safety legislation, and trends in reported injury and illness rates suggests that the priority given to health and safety in Japan has dramatically shifted over the last seventy years. Between 1950 and 1985, Japan went from a reported injury rate on average four times higher than that found in the United States to a level less than half of that reported by the average American firm. In industries such as automobiles the change is even more dramatic. In plants employing more than 1,000 workers, American employers reported thirty times more accidents per worker than comparable Japanese plants.

How can this dramatic turnaround in relative health and safety performance be explained? Wokutch dismisses the hypothesis that Japanese employers are motivated by different ethical or moral concerns, although this does become somewhat confusing when he discusses the relationship between paternalistic employment philosophies and approaches to health and safety. Instead he sees Japanese employers guided by enlightened self-interest. Central to Wokutch's explanation of the success of the Japanese in dealing with health and safety is the relationship between health and safety practices and constraints created within the Japanese system of lean production. Lean production, which strives for $100 \%$ use of a worker's time, and involves minimal levels of inventories between work stations, dictates that accidents be kept to a minimum as there is 